\title{
The Effect of Antidiuretic Hormone
}

\section{on Solute Flows in Mammalian Collecting Tubules}

\author{
James A. Schafer and Thomas E. ANDreoli \\ From the Departments of Medicine (Division of Nephrology) \\ and Physiology, University of Alabama Medical Center, \\ Birmingham, Alabama 35233
}

A B STRACT These experiments were intended to evaluate the antidiuretic hormone (ADH)-dependent reflection coefficients of urea, sucrose, and $\mathrm{NaCl}$ in cortical and outer medullary collecting tubules isolated from mammalian kidney. In one group of experiments, the $\mathrm{ADH}$-dependent osmotic water flows, when the perfusing solutions contained hypotonic $\mathrm{NaCl}$ solutions, were indistinguishable from control observations when either urea or sucrose replaced, in part, $\mathrm{NaCl}$ in isotonic bathing solutions (cortical collecting tubules). Similarly, both in cortical and outer medullary collecting tubules exposed to $\mathrm{ADH}$, there was zero net osmotic volume flow when a portion of the $\mathrm{NaCl}$ in the bathing and/or perfusing solutions was replaced by either sucrose or urea, so long as the perfusing and bathing solutions were isosmolal. Taken together, these observations suggest that the $\mathrm{ADH}$-dependent reflection coefficients of $\mathrm{NaCl}$, urea, and sucrose, in these tubules, were identical. Since the effective hydrodynamic radii of urea and sucrose are, respectively, 1.8 and $5.2 \mathrm{~A}$, it is likely that $\sigma_{1}$, for urea, sucrose, and $\mathrm{NaCl}$, was unity. In support of this, the diffusion permeability coefficient $\left(\mathrm{P}_{\mathrm{D}_{\mathrm{i}}}, \mathrm{cm} \mathrm{sec}{ }^{-1}\right)$ of urea was indistinguishable from zero. Since the limiting sites for urea penetration were the luminal interfaces of the tubules, these data are consistent with the view that $\mathrm{ADH}$ increases diffusional water flow across such interfaces.

Preliminary reports of this work have appeared in abstract form $(9,10)$.

Dr. Schafer is an Established Investigator of the American Heart Association. Dr. Andreoli holds a Research Career Development Award from the National Institute of General Medical Sciences.

Received for publication 26 October 1971 and in revised form 26 December 1971.

\section{INTRODUCTION}

The experiments described in the preceding paper (1), in agreement with earlier observations $(2-4)$, indicated that antidiuretic hormone $(\mathrm{ADH})^{1}$ increased the water permeability of the luminal interfaces (plasma membranes and/or tight junctions) of cortical collecting tubule segments from rabbit kidney. Under these conditions, the discrepancy between the $\mathrm{ADH}$-dependent osmotic $\left(\mathrm{P}_{\mathbf{r}}, \mathrm{cm} \mathrm{sec}{ }^{-1}\right)$ and diffusional $\left(\mathrm{P}_{\mathrm{D}_{\mathrm{w}}}, \mathrm{cm} \mathrm{sec} \mathrm{se}^{-1}\right)$ water permeability coefficients was rationalized in terms of cellular constraints to diffusion, rather than as a consequence of laminar water flow through aqueous membrane pores during osmosis (1). Stated alternatively, we assumed that the ADH-dependent increments in water permeability might be referable solely to an increased rate of water diffusion in the luminal interfaces of these tubules (1).

Such an hypothesis requires that there be no appreciable degree of molecular seiving, on a size basis, for hydrophilic nonelectrolytes (5-8). The present experiments were designed to test this possibility. The results indicate that the ADH-dependent reflection coefficients $\left(\sigma_{1}\right)$ for $\mathrm{NaCl}$, urea, and sucrose are each unity at the luminal interfaces of cortical and outer medullary collecting tubules. Similarly, the diffusional permeability coefficients for urea and thiourea $\left(\mathrm{P}_{\mathrm{D}_{\mathrm{i}}}\right)$ in these tubules are negligibly small with respect to $\mathrm{P}_{\mathbf{D}_{\mathbf{w}}}$, and unaffected by $\mathrm{ADH}$.

Preliminary results of some of the studies described in this paper have been presented elsewhere $(9,10)$.

\section{METHODS}

Isolation and perfusion of tubule segments. The procedures for dissecting and perfusing segments of rabbit cortical

${ }^{1}$ Abbreviations used in this paper: $\mathrm{ADH}$, antidiuretic hormone; KRB, Krebs-Ringer bicarbonate; KRP, KrebsRinger phosphate. 
collecting tubules have been described in the preceding article (1). With minor modification, these techniques are identical with those described originally by Burg, Grantham, Abramow, and Orloff (11). In the present studies, we utilized both cortical and outer medullary collecting tubules. In order to obtain segments of the latter, the kidney was removed and sliced as described previously (1). The 2-3 mm thick crosssectional slice was observed to have a dark red-brown stripe at the corticomedullary junction. The cortex was separated from the medulla at this boundary by means of a microscalpel, and was discarded.

The remaining slice of medulla was then dissected by stripping small bundles of parallel tubules from the papilla toward the outer medulla. The final isolation of a medullary collecting tubule was considerably more complicated than the isolation of cortical segments, due to the presence of bifurcations. The medullary tubules which were used in the present experiments had no bifurcations along their length and had an intact basement membrane. Our impression, based on the microdissections, is that all such segments came from the the outer two-thirds of the medulla and that they were derived from a single nephron rather than from the confluence of several other collecting tubules. The inside and outside diameters of the medullary tubules, like cortical collecting tubules, were $22-25 \mu$ and $35-40 \mu$, respectively; their appearance under the light microscope $(\times 50-600)$ was also identical with that of the cortical collecting tubules.

The mounting and perfusion procedures were the same as were used for the cortical segments. All tubules were bathed in various Krebs-Ringer bicarbonate buffers (KRB) and perfused at flow rates of $10-25 \mathrm{nl} \mathrm{min}^{-1}$ at a constant temperature of $25 \pm 0.5^{\circ} \mathrm{C}$ (1).

Buffer solutions. The solutions used for perfusing and bathing the tubules were similar to those described in the preceding article (1). Three perfusing solutions were used: (a) An isotonic (290 mOsm liter ${ }^{-1}$ ) Krebs-Ringer phosphate (KRP) buffer containing $150 \mathrm{mEq}$ liter $^{-1} \mathrm{NaCl}, 2.5 \mathrm{mEq}$ liter ${ }^{-1} \mathrm{~K}_{2} \mathrm{HPO}_{4}, 1.0 \mathrm{mEq}$ liter ${ }^{-1} \mathrm{CaCl}_{2}$, and $1.2 \mathrm{mEq}$ liter ${ }^{-1}$ $\mathrm{MgSO}_{4}$. (b) A hypotonic (125 mOsm liter ${ }^{-1}$ ) KRP buffer having the same composition as the isotonic buffer, but with only $60 \mathrm{mEq}$ liter ${ }^{-1} \mathrm{NaCl}$. (c) An isotonic $(290 \mathrm{mOsm}$ liter $^{-1}$ ) KRP buffer identical in composition with the isotonic medium above but with variable amounts of the $\mathrm{NaCl}$ replaced by butanol, urea, or sucrose. These solutions contained $125 \mathrm{mOsm}$ liter $^{-1} \mathrm{NaCl}$ and $165 \mathrm{mOsm} \mathrm{liter}{ }^{-1}$ of either urea, sucrose, or butanol. They are indicated in the text as 125 mOsm liter ${ }^{-1} \mathrm{KRP}+165 \mathrm{mOsm}^{-1}$ liter $^{-1}$ of either urea, sucrose, or butanol. All KRP solutions were adjusted to $\mathrm{pH}$ 7.4 by the addition of small volumes of $0.1 \mathrm{~N} \mathrm{HCl}$.

The bathing solutions were: (a) An isotonic $(290 \mathrm{mOsm}$ liter $^{-1}$ ) Krebs-Ringer bicarbonate (KRB) buffer of the following composition: $115 \mathrm{mEq}$ liter ${ }^{-1} \mathrm{NaCl}, 25 \mathrm{mEq}$ liter $^{-1}$ $\mathrm{NaHCO}_{3}, 10 \mathrm{mEq}$ liter ${ }^{-1} \mathrm{Na}$ acetate, $1.0 \mathrm{mEq} \mathrm{liter}{ }^{-1} \mathrm{CaCl}_{2}$, $1.2 \mathrm{mEq}$ liter ${ }^{-1} \mathrm{MgSO}_{4}$, and $5.5 \mathrm{~mm}$ glucose. To this mixture $5 \%(\mathrm{v} / \mathrm{v})$ calf serum (Microbiological Associates, Inc., Bethesda, Md.) was added. (b) A hypertonic (455 mOsm liter $^{-1}$ ) KRB buffer, identical with isotonic KRB buffer except that it contained $200 \mathrm{mEq}$ liter $^{-1} \mathrm{NaCl}$. (c) An isotonic (290 mOsm liter ${ }^{-1}$ ) $\mathrm{KRB}$ buffer in which a variable portion of the $\mathrm{NaCl}$ was substituted by butanol, urea, or sucrose. (d) A hyperosmotic (455 mOsm liter ${ }^{-1}$ ) KRB buffer in which a portion of the $\mathrm{NaCl}$ was substituted by butanol, urea, or sucrose. Abbreviations similar to those for perfusing media were used for these buffers.

Net osmotic water fux experiments. Net water flows were computed from the difference between the rate of per- fusion and the rate of collection, and the tubule inner surface area as described previously (1). The perfusion rate was calculated from the rate of appearance of inulin methoxy- ${ }^{3} \mathrm{H}$ in the collected fluid, and the collection rate was calculated from the volume collected and the duration of the collection period. $\sigma_{1} \mathrm{~L}_{\mathrm{p}}$, the product of the reflection coefficient of the ith solute and the coefficient of hydraulic conductivity $(\mathrm{cm}$ sec $\mathrm{atm}^{-1}$ ), was computed from the net water flows (1), and $P_{\mathbf{f}}$, the osmotic water permeability coefficient, was calculated from $L_{p}$ and the relation (12):

$$
\mathrm{P}_{\mathrm{f}}=\sigma_{\mathrm{i}} \mathrm{L}_{\mathrm{p}} \frac{R T}{\bar{\nabla}_{\mathrm{w}}},
$$

where: $R$ is the gas constant, $T$ is the absolute temperature and $\bar{V}_{w}$ is the partial molal volume of water.

If it is assumed that the value of $L_{p}$ is independent of the solute used to produce the osmotic pressure difference, then the ratio of the reflection coefficients of two solutes, $i$ and $j$, should be equal to the ratio of the $P_{t}$ values observed with these solutes:

$$
\frac{\sigma_{i}}{\sigma_{j}}=\frac{P_{f}^{i}}{P_{f}^{j}} .
$$

Equation 2 has been used to obtain the ratios of the reflection coefficients for different solutes in these tubules.

Tubular permeability to urea and thiourea. The methods used for measuring solute diffusional permeability coefficients $\left.\left(P_{D_{\mathbf{1}}}, \mathrm{cm} \mathrm{sec}\right)^{-1}\right)$ are identical with those used in the preceding paper (1). The perfusing solutions contained inulinmethoxy- ${ }^{3} \mathrm{H}$ (New England Nuclear, Boston, Mass., 80-250 $\mathrm{mCi} / \mathrm{g}$ ) at a final activity of $50-100 \mu \mathrm{Ci} / \mathrm{ml}$ and the ${ }^{14} \mathrm{C}$ labeled test solute: either urea- ${ }^{14} \mathrm{C}$ (New England Nuclear; $0.83 \mathrm{mCi} / \mathrm{mg}$, lot No. $283-154,25 \mu \mathrm{Ci} \mathrm{m}^{-1}$ of perfusion solution) or thiourea (Calbiochem; SA $18 \mathrm{mCi} \mathrm{mmole}^{-1}$, lot

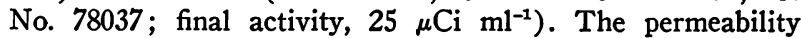
coefficient was calculated from the flow rate, the tubule inner surface area, and the difference between activities of the solute in the perfused and collected fluids. Since the experiments were carried out at zero volume flow, equation 3 from the preceding paper was used to compute $P_{D}(1)$.

Other procedures. The remaining experimental procedures and reagents are identical with those in the preceding paper (1).

\section{RESULTS}

The effect of varying bath composition on $P_{r}$. In these experiments, we measured the ADH-dependent values of $P_{2}$ from the osmotic water fluxes, lumen to bath, in the presence of various bathing media. Two sets of experiments were carried out. In the first group, the perfusing solutions contained $290 \mathrm{mOsm}$ liter $^{-1}$ $\mathrm{KRP}$, and the bathing solutions were either $455 \mathrm{mOsm}$ liter $^{-1} \mathrm{KRB}$, or $455 \mathrm{mOsm}$ liter ${ }^{-1} \mathrm{KRB}$ buffer in which a portion of the $\mathrm{NaCl}$ had been replaced with either urea or sucrose. In the second set of experiments, the perfusion solutions contained 125 mOsm liter ${ }^{-1} \mathrm{KRP}$, and the bathing solutions were either 290 mOsm liter ${ }^{-1}$ $\mathrm{KRB}$ or $290 \mathrm{mOsm}$ liter $^{-1} \mathrm{KRB}$ buffer in which a portion of the $\mathrm{NaCl}$ had been replaced by either urea, 
sucrose, or $n$-butanol. Accordingly, it was possible to compare the "effectiveness" of these solutes in terms of the ADH-dependent transtubular osmotic water fluxes. The results of all such experiments are presented in Table I.

It is evident that there were substantial differences in the $\mathrm{ADH}$-dependent values of $\mathrm{P}_{\mathrm{r}}$ among tubules when differences in the $\mathrm{NaCl}$ concentrations in the luminal and bathing fluids were primarily responsible for the osmotic pressure gradient; e.g., when the perfusing and bathing solutions contained, respectively, $125 \mathrm{mOsm}$ liter $^{-1} \mathrm{KRP}$ and $290 \mathrm{mOsm} \mathrm{liter}{ }^{-1} \mathrm{KRB}, \mathrm{P}_{\mathrm{s}}$ varied from
$131 \mathrm{~cm} \mathrm{sec}^{-1}$ (Table I, tubule C30) to $239 \mathrm{~cm} \mathrm{sec}^{-1}$ (Table I, tubule C22). Accordingly, comparisons of the $P_{t}$ values when different solutes were in the bathing media were made in individual tubules. The order of addition of the various solutes to the bathing media, not shown in Table I, was randomized deliberately.

Table I indicates that, for a given tubule, the ADHdependent values of $J_{w}$, and accordingly $P_{f}$, were the same, within experimental error, when a portion of the $\mathrm{NaCl}$ in the bathing solutions was replaced by urea. These results obtained for either hypertonic ( $455 \mathrm{mOsm}$ liter ${ }^{-1}$, tubules C6 and C12) or isotonic (290 mOsm

TABLE I

The Effect of Varying Bath Composition on Osmotic Water Flow in Cortical Collecting Tubules

\begin{tabular}{|c|c|c|c|c|}
\hline Tubule & $\begin{array}{l}\text { Perfusing } \\
\text { medium }\end{array}$ & Bathing medium & $\mathrm{J}_{\mathbf{w}}$ & $\mathbf{P}_{\mathrm{f}}$ \\
\hline & & $m O_{s m}$ liler $^{-1}$ & $\mathrm{~cm}^{3} \mathrm{sec}^{-1} \mathrm{~cm}^{-2} \times 10^{5}$ & $\mathrm{~cm} \mathrm{sec}^{-1} \times 10^{4}$ \\
\hline C6 & $290 \underset{\text { KRP }}{\mathrm{K} R}$ & $\begin{array}{l}455 \mathrm{KRB} \\
290 \mathrm{KRB}+165 \text { urea }\end{array}$ & $\begin{array}{l}-4.41 \pm 0.37(6) \\
-4.13 \pm 0.36(5)\end{array}$ & $\begin{array}{l}232 \pm 19 \\
217 \pm 18 \ddagger\end{array}$ \\
\hline $\mathrm{C} 12$ & $\begin{array}{c}290 \mathrm{KRP} \\
\text { “" }\end{array}$ & $\begin{array}{l}290 \text { KRB + } 165 \text { sucrose } \\
290 \text { KRB + } 165 \text { urea } \\
455 \text { KRB }\end{array}$ & $\begin{array}{l}-4.58 \pm 0.57(6) \\
-4.34 \pm 0.38(3) \\
-3.67 \pm 0.30(3)\end{array}$ & $\begin{array}{l}226 \pm 33 \\
214 \pm 17 \S \\
181 \pm 16 \ddagger\end{array}$ \\
\hline $\mathrm{C} 18$ & $125 \underset{6}{\mathrm{KRP}}$ & $\begin{array}{l}290 \mathrm{KRB} \\
225 \mathrm{KRB}+65 \text { urea }\end{array}$ & $\begin{array}{l}-4.35 \pm 0.53(5) \\
-4.56 \pm 0.21\end{array}$ & $\begin{array}{l}220 \pm 27 \\
211 \pm 10 \S\end{array}$ \\
\hline $\mathrm{C} 22$ & "“ & $\begin{array}{l}290 \mathrm{KRB} \\
225 \mathrm{KRB}+65 \text { urea }\end{array}$ & $\begin{array}{l}-5.10 \pm 0.70(6) \\
-5.08 \pm 0.69\end{array}$ & $\begin{array}{l}239 \pm 33 \\
238 \pm 32 \S\end{array}$ \\
\hline $\mathrm{C} 23$ & “" & $\begin{array}{l}290 \mathrm{KRB} \\
175 \mathrm{KRB}+65 \text { urea } \\
175 \mathrm{KRB}+115 \text { urea }\end{array}$ & $\begin{array}{l}-2.29 \pm 0.23(5) \\
-1.78 \pm 0.22(3) \\
-1.97 \pm 0.50\end{array}$ & $\begin{array}{l}143 \pm 14 \\
118 \pm 15 \ddagger \\
126 \pm 37 \S\end{array}$ \\
\hline $\mathrm{C} 25$ & $\begin{array}{l}\text { “" } \\
\text { “" } \\
\text { “" }\end{array}$ & $\begin{array}{l}290 \mathrm{KRB} \\
225 \mathrm{KRB}+65 \text { urea } \\
175 \mathrm{KRB}+115 \text { urea } \\
125 \mathrm{KRB}+165 \text { sucrose }\end{array}$ & $\begin{array}{l}-4.34 \pm 0.31(9) \\
-4.13 \pm 0.43(3) \\
-4.38 \pm 0.30(3) \\
-4.38 \pm 0.35\end{array}$ & $\begin{array}{l}170 \pm 17 \\
174 \pm 19 \S \\
186 \pm 17 \ddagger \\
186 \pm 20 \ddagger\end{array}$ \\
\hline $\mathrm{C} 29$ & $\begin{array}{l}\text { " } \\
\text { “ } \\
\text { “ } \\
\text { “ }\end{array}$ & $\begin{array}{l}290 \mathrm{KRB} \\
225 \mathrm{KRB}+65 \text { urea } \\
175 \mathrm{KRB}+115 \text { urea } \\
125 \mathrm{KRB}+165 \text { urea } \\
125 \mathrm{KRB}+165 \text { sucrose }\end{array}$ & $\begin{array}{l}-4.46 \pm 0.51(6) \\
-4.72 \pm 0.47(3) \\
-4.47 \pm 0.32(3) \\
-4.22 \pm 0.05 \\
-4.38 \pm 0.21\end{array}$ & $\begin{array}{l}186 \pm 20 \\
197 \pm 21 \S \\
189 \pm 13 \S \\
178 \pm 1 \S \\
182 \pm 9 \S\end{array}$ \\
\hline C30 & “ & $\begin{array}{l}290 \mathrm{KRB} \\
125 \mathrm{KRB}+165 \text { sucrose }\end{array}$ & $\begin{array}{l}-3.12 \pm 0.06(6) \\
-3.53 \pm 0.02(3)\end{array}$ & $\begin{array}{l}131 \pm 11 \\
146 \pm 1 \ddagger\end{array}$ \\
\hline $\mathrm{C} 32$ & “" & $\begin{array}{l}290 \mathrm{KRB} \\
175 \mathrm{KRB}+115 \text { butanol }\end{array}$ & $\begin{array}{l}-3.04 \pm 0.58(3) \\
-0.87 \pm 0.37\end{array}$ & $\begin{array}{r}140 \pm 25 \\
48 \pm 18^{*}\end{array}$ \\
\hline $\mathrm{C} 34$ & $\begin{array}{l}\text { “ } \\
\text { “ }\end{array}$ & $\begin{array}{l}290 \mathrm{KRB} \\
175 \mathrm{KRB}+115 \text { butanol } \\
175 \mathrm{KRB}+115 \text { sucrose }\end{array}$ & $\begin{array}{l}-4.70 \pm 0.31 \\
-1.89 \pm 0.20(3) \\
-4.21 \pm 0.33\end{array}$ & $\begin{aligned} 177 & \pm 28 \\
69 & \pm 18^{*} \\
175 & \pm 31 \S\end{aligned}$ \\
\hline
\end{tabular}

$\mathrm{ADH}, 250 \mu \mathrm{U} \mathrm{ml}^{-1}$, was present uniformly in the bathing solutions. $\mathrm{J}_{w}$ was taken to be negative for net water efflux, lumen to bath; $J_{w}$ was expressed as the mean \pm standard deviation for the number of flux periods shown in parentheses. Probability values for the comparison of the average $\mathrm{P}_{t}$ in the presence of $290 \mathrm{KRB}$ to that in other bathing solutions were computed from the Student $t$ test. $\left(^{*}=P<0.01 ; \ddagger=P>0.1 ; \S=P>0.5\right)$. 
liter ${ }^{-1}$, tubules $\mathrm{C} 18, \mathrm{C} 22, \mathrm{C} 23$, and $\mathrm{C} 25$ ) bathing fluids. Similarly, when sucrose was substituted for $\mathrm{NaCl}$ in the bathing solutions ( $455 \mathrm{mOsm} \mathrm{liter} \mathrm{m}^{-1}$, tubule $\mathrm{C} 12$; 290 mOsm liter ${ }^{-1}$, tubules C25, C29, C30, C34), the values of $\mathrm{J}_{w}$ and $\mathrm{P}_{f}$ did not change significantly. In this regard, it should be noted that, when the bathing media were hypertonic and contained either urea or sucrose (tubules $\mathrm{C} 6$ and $\mathrm{C12}$ ), the test solute was entirely responsible for the transtubular osmotic pressure gradient.

The diffusional permeability coefficient of the lipophilic species $n$-butanol in these tubules is only slightly less than the $\mathrm{ADH}$-dependent value of $\mathrm{P}_{\mathrm{D}_{\mathrm{w}}}$ (1). Accordingly, it is reasonable to infer that $\sigma_{1}$ for butanol in these tubules is low. In this regard, when a portion of the $\mathrm{NaCl}$ in the bathing media was replaced by butanol, osmotic water flow was reduced significantly (Table I, tubules C32 and C34). Based on the control observations (when the bathing solutions contained 290 mOsm liter ${ }^{-1} \mathrm{KRB}$ ), the predicted water flows referable to the $\mathrm{NaCl}$ gradient (for $175 \mathrm{mOsm}$ liter $^{-1}$ KRB bathing solutions) were $0.89 \times 10^{-5} \mathrm{~cm}^{3} \mathrm{sec}^{-1} \mathrm{~cm}^{-2}$ and $1.4 \times 10^{-5} \mathrm{~cm}^{3} \mathrm{sec}^{-1} \mathrm{~cm}^{-2}$ for, respectively, tubules C32 and C34 (Table I). Table I (tubules C32 and C34) indicates that the addition of butanol to the bathing solutions resulted in little, if any, detectable osmotic volume flow, in agreement with the view that $\sigma_{1}$ for butanol was near zero. Further, since the observed water flows when butanol was added to the bathing solutions (Table I, tubules C32 and C34) were in reasonable accord with those predicted solely from transtubular differences in $\mathrm{NaCl}$ concentrations (above), it is likely that the butanol in the bathing solutions did not affect significantly the osmotic water permeability of these tubules.

The ratios of the different $P_{f}$ values for bathing solutions of varying composition in a given tubule are listed in Table II. Within the limits of experimental

\section{TABLE II}

The Ratio $P_{f}^{a} / P_{f}^{b}$ in Cortical Collecting Tubules

$\frac{\mathrm{P}_{\mathrm{f}}^{\text {urea }}}{\mathrm{P}_{\mathrm{f}}^{\mathrm{NaCl}}}=1.01 \pm 0.11$
$\frac{\mathrm{P}_{\mathrm{f}}^{\text {urea }}}{\mathrm{P}_{\mathrm{f}}^{\text {sucrose }}}=0.97 \pm 0.08$
$\frac{\mathrm{P}_{\mathrm{f}}^{\text {sucrose }}}{\mathrm{P}_{\mathrm{f}}^{\mathrm{NaCl}}}=1.08 \pm 0.11$

The ratios of the osmotic water permeability coefficients were obtained from the mean $P_{f}$ values shown in Table II for bathing solutions of varying composition. The results are expressed as mean $\pm \mathrm{SD}$ for the numbers of tubules shown in parentheses. error, each ratio was approximately unity. Accordingly, if it is assumed that $L_{p}$ (equation 1) remained constant, these data indicate clearly that the ADH-dependent value of $\sigma_{1}$ in these tubules was the same, for $\mathrm{NaCl}$, urea, and sucrose.

Solute reflection coefficients at zero volume flow. We wished also to evaluate the solute reflection coefficients at zero volume flow. In these experiments, the osmolalities of the perfusing and bathing media were both $290 \mathrm{mOsm}$ liter $^{-1}$. However, various solutes (urea, sucrose, and butanol) were substituted in part for $\mathrm{NaCl}$ in these solutions. The results of such experiments with cortical and outer medullary collecting tubules are shown in, respectively, Tables III and IV. All the reported flux periods were conducted in the presence of $250 \mu \mathrm{U} \mathrm{ml}^{-1} \mathrm{ADH}$. It is evident that, regardless of the combination of $\mathrm{NaCl}$, urea, or sucrosesubstituted solutions used, the net water flows were not significantly different from zero as long as the total osmolalities of the perfusing and bathing solutions were both $290 \mathrm{mOsm}$ liter $^{-1}$. In certain instances, $455 \mathrm{mOsm}$ liter $^{-1} \mathrm{KRB}$ was also added to the bathing solutions (Table III, tubules C35, C37, C38; Table IV, tubule M4). The resultant values of $J_{w}$ were in accord with the comparable values in Table I. Thus, the results of these zero volume flow experiments, in agreement with the osmotic flow experiments (Table I), suggest that the reflection coefficients of $\mathrm{NaCl}$, urea, and sucrose were identical, both in the cortical (Table III) and outer medullary (Table IV) collecting tubules.

In one experiment (Table III, tubule C41), the tubule was perfused with an isosmotic solution containing $n$-butanol as the major solute. In this case, large net water flows were observed in the presence of isosmotic bathing media containing either $\mathrm{NaCl}$, urea, or sucrose as the major solute. The values of $\mathrm{J}_{\mathrm{w}}$ in this experiment are within the range of the ADH-dependent values for $\mathrm{J}_{\mathrm{w}}$ listed in Table $\mathrm{I}$ for perfusing and bathing solutions containing, respectively, $125 \mathrm{mOsm}$ liter $^{-1} \mathrm{KRP}$ and $290 \mathrm{mOsm}$ liter $^{-1} \mathrm{KRB}$. These data imply, first, that $\sigma_{1}$ for butanol in the cortical collecting tubules is near zero, and second, that the addition of butanol to the perfusing solutions did not modify significantly the osmotic water permeability of these tubules.

The rate-limiting site for solute penetration. There is reasonable experimental evidence to indicate that $\mathrm{ADH}$ increases the water permeability of the luminal interfaces of these tubules (1-4). In order to establish the location of the limiting barrier to solute penetration, the following experiment was conducted. Cortical collecting tubules were perfused with a solution of 125 mOsm liter ${ }^{-1} \mathrm{KRP}$ plus $165 \mathrm{mOsm}$ liter $^{-1}$ urea; the bathing solution contained $250 \mu \mathrm{U} \mathrm{ml}^{-1}$ ADH and 290 
TABLE III

Cortical Collecting Tubules: the Effect of Varying Perfusing and Bathing Media at Zero

Volume Flow

\begin{tabular}{|c|c|c|c|}
\hline Tubule & Perfusing medium & Bathing medium & $\mathrm{J}_{\mathrm{w}}$ \\
\hline & \multicolumn{2}{|c|}{$m O_{s m}$ liter $^{-1}$} & $\mathrm{~cm}^{3} \mathrm{sec}^{-1} \mathrm{~cm}^{-2} \times 10^{5}$ \\
\hline C35 & $125 \mathrm{KRP}+\underset{\text { ، }}{165}$ & $\begin{array}{l}290 \mathrm{KRB} \\
455 \mathrm{KRB}\end{array}$ & $\begin{array}{l}+0.20 \pm 0.30 \\
-2.33 \pm 0.07\end{array}$ \\
\hline $\mathrm{C} 37$ & $\begin{array}{c}125 \mathrm{KRP}+165 \text { urea } \\
، \\
، \\
،\end{array}$ & $\begin{array}{l}290 \mathrm{KRB} \\
125 \mathrm{KRB}+165 \text { sucrose } \\
125 \mathrm{KRB}+165 \text { urea } \\
455 \mathrm{KRB}\end{array}$ & $\begin{array}{l}+0.08 \pm 0.82(4) \\
-0.19 \pm 0.12(3) \\
-0.31 \pm 0.37(3) \\
-4.40 \pm 0.02\end{array}$ \\
\hline $\mathrm{C} 47$ & $125 \mathrm{KRP}+165$ urea & $290 \mathrm{KRB}$ & $+0.04 \pm 0.28$ \\
\hline C38 & $\begin{array}{c}125 \mathrm{KRP}+165 \text { sucrose } \\
، \\
، \\
\text { “ }\end{array}$ & $\begin{array}{l}290 \mathrm{KRB} \\
125 \mathrm{KRB}+165 \text { sucrose } \\
125 \mathrm{KRB}+165 \text { urea } \\
455 \mathrm{KRB}\end{array}$ & $\begin{array}{l}+0.19 \pm 0.28(4) \\
+0.23 \pm 0.20(3) \\
+0.23 \pm 0.18 \\
-2.83 \pm 0.23\end{array}$ \\
\hline $\mathrm{C} 41$ & $\begin{array}{c}125+165 \text { butanol } \\
\text { "، }\end{array}$ & $\begin{array}{l}290 \mathrm{KRB} \\
125 \mathrm{KRB}+165 \text { sucrose } \\
125 \mathrm{KRB}+165 \text { urea }\end{array}$ & $\begin{array}{l}-3.86 \pm 0.42(4) \\
-3.46 \pm 0.13(3) \\
-3.01 \pm 0.51\end{array}$ \\
\hline
\end{tabular}

$\mathrm{ADH}, 250 \mu \mathrm{U} \mathrm{ml}^{-1}$, was present uniformly in the bathing solutions. $\mathrm{J}_{\mathrm{w}}$ was expressed as the mean \pm SD for the numbers of flux periods shown in parentheses.

mOsm liter ${ }^{-1} \mathrm{KRB}$; as shown in Table III, these conditions result in zero volume flow. Fig. 1 shows the appearance of a tubule under these conditions. At 248 min, the tubular cells were flat and there was no measurable net water flow. At $251 \mathrm{~min}$, the bathing solution was changed to a solution of $125 \mathrm{mOsm}$ liter $^{-1}$ $\mathrm{KRB}$ plus $165 \mathrm{mOsm}$ liter ${ }^{-1}$ urea with $250 \mu \mathrm{U} \mathrm{\textrm {ml } ^ { - 1 }}$ ADH. Within $1 \mathrm{~min}$ (Fig. 1, $252 \mathrm{~min}$ ), the tubular cells began swelling. The swelling became progressively more evident at 3 and 7 min (Fig. 1, 254 and $258 \mathrm{~min}$ ) after the introduction of the new bathing solution. However, no net transtubular water flow was measurable (Table III). The fact that the same solu- tion (i.e., 125 mOsm liter ${ }^{-1} \mathrm{KRP}+165$ mOsm liter $^{-1}$ urea) caused no cellular swelling when on the luminal side of the epithelium indicates that the luminal interfaces of these tubules must be rate-limiting to urea penetration. The rapidity with which the bathing solution containing urea caused cellular swelling suggests that the peritubular basement membranes must be quite permeable to this solute, especially in comparison to the luminal interfaces.

Permeability coefficients of urea and thiourea in cortical collecting tubules. In order to assess further the solute permeability of cortical collecting tubules, the diffusional permeability coefficients of urea and thiourea

TABLE IV

Outer Medullary Collecting Tubules: the Effect of Varying Perfusing and Bathing Media at Zero Volume Flow

\begin{tabular}{|c|c|c|c|}
\hline Tubule & Perfusing medium & Bathing medium & $\mathrm{J}_{\mathrm{w}}$ \\
\hline & \multicolumn{2}{|c|}{$m O s m$ liter $^{-1}$} & $\mathrm{~cm}^{3} \mathrm{sec}^{-1} \mathrm{~cm}^{-2} \times 10^{5}$ \\
\hline M2 & $125 \mathrm{KRP}+165$ urea & $290 \mathrm{KRB}$ & $-0.02 \pm 0.54(14)$ \\
\hline \multirow[t]{2}{*}{ M3 } & “ & $290 \mathrm{KRB}$ & $+0.39 \pm 0.51(17)$ \\
\hline & “ & $125 \mathrm{KRB}+165$ sucrose & $0.00 \pm 0.42$ \\
\hline \multirow[t]{3}{*}{ M4 } & “ & $290 \mathrm{KRB}$ & $-0.18 \pm 0.21$ \\
\hline & “ & $125 \mathrm{KRB}+162$ sucrose & $-0.18 \pm 0.13$ \\
\hline & “ & $455 \mathrm{KRB}$ & $-2.09 \pm 0.20$ \\
\hline
\end{tabular}

ADH, $250 \mu \mathrm{U} \mathrm{ml}^{-1}$, was present uniformly in the bathing solutions. $\mathrm{J}_{\mathrm{w}}$ was expressed as mean \pm SD for the number of flux periods shown in parentheses. 


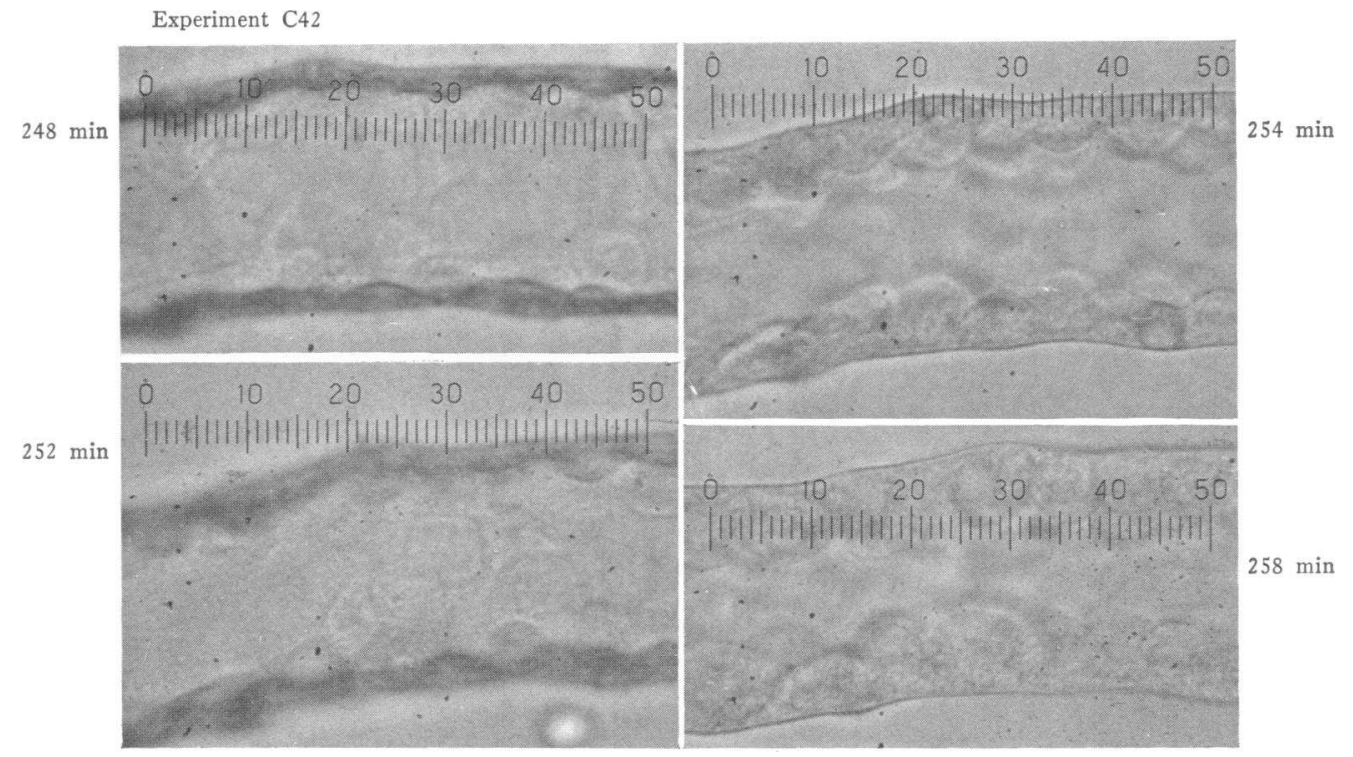

FIGURE 1 The appearance of a cortical collecting tubule in the presence of perfusing and/or bathing solutions containing urea. $\mathrm{ADH}, 250 \mu \mathrm{U} \mathrm{ml^{-1 }}$, was present uniformly in the bathing solutions (magnification $=\times 480 ;$ scale $=2.13 \mu$ per division).

were determined in three different situations: first, in the absence of an osmotic gradient and with no $\mathrm{ADH}$ present; second, under the same conditions with 250 $\mu \mathrm{U} \mathrm{ml}^{-1} \mathrm{ADH}$ in the bathing medium; and third, in the presence of an osmotic gradient (290 mOsm liter ${ }^{-1}$ KRP perfusing fluid and 455 mOsm liter ${ }^{-1} \mathrm{KRB}$ plus $250 \mu \mathrm{U} \mathrm{ml} \mathrm{m}^{-1} \mathrm{ADH}$ bathing fluid). Table $\mathrm{V}$ indicates that, in each of these three conditions, the values of $\mathbf{P}_{\mathbf{p}_{\mathbf{i}}}$, for either urea or thiourea, were not significantly different from zero. Burg, Helman, Grantham, and Orloff have also noted that $\mathrm{P}_{\mathbf{D}_{\mathbf{i}}}$ for both urea and thiourea is vanishingly small, with respect to the diffusional permeability coefficient for water, both in the absence and presence of $\operatorname{ADH}(2,13)$.

\section{DISCUSSION}

The Staverman factor (14), or reflection coefficient $\left(\sigma_{1}\right)$, is a measure of the permeability of a membrane to a solute species with respect to solvent. For a given membrane, $\sigma_{1}$ may be expressed as (14):

$$
\sigma_{\mathrm{i}}=\left(\frac{\pi_{\text {obs }}}{\pi_{\text {pred }}}\right) J_{\mathrm{v}}=0,
$$

where $\pi_{\text {pred }}$ is the predicted osmotic pressure of a solution of the ith solute, determined from a colligative property such as freezing point depression; and, $\pi_{\text {obs }}$ is the observed osmotic pressure of such a solution in contact with a membrane, defined as the opposing hy-

TABLE V

The Diffusional Permeability Coefficients of Urea and Thiourea in Cortical Collecting Tubules

\begin{tabular}{|c|c|c|c|c|c|c|}
\hline Tubule & Solute & $\begin{array}{l}\text { Perfusing } \\
\text { medium }\end{array}$ & $\begin{array}{l}\text { Bathing } \\
\text { medium }\end{array}$ & $\mathrm{ADH}$ & $J_{\pi}$ & $P_{D_{\mathfrak{i}}}$ \\
\hline & & \multicolumn{2}{|c|}{$m O s m$ liter $^{-1}$} & $\mu U m l^{-1}$ & $\mathrm{~cm}^{2} \mathrm{sec}^{-1} \mathrm{~cm}^{2} \times 10^{5}$ & $\mathrm{~cm} \mathrm{sec}^{-1} \times 10^{4}$ \\
\hline $\mathrm{P} 27$ & urea & $\begin{array}{c}290 \mathrm{KRP} \\
، \\
“\end{array}$ & $\begin{array}{c}290 \mathrm{KRB} \\
\text { “ } \\
455 \mathrm{KRB}\end{array}$ & $\begin{array}{r}0 \\
250 \\
250\end{array}$ & $\begin{array}{l}+0.61 \pm 0.34 \\
+0.65 \pm 0.54 \\
-3.93 \pm 0.61\end{array}$ & $\begin{array}{l}0.03 \pm 0.15 \\
0.02 \pm 0.21 \\
0.02 \pm 0.18\end{array}$ \\
\hline P28 & thiourea & $\begin{array}{c}290 \mathrm{KRP} \\
\text { “، }\end{array}$ & $\begin{array}{c}290 \mathrm{KRB} \\
“ \\
455 \mathrm{KRB}\end{array}$ & $\begin{array}{r}0 \\
250 \\
250\end{array}$ & $\begin{array}{l}-0.43 \pm 0.79 \\
+0.36 \pm 0.83 \\
-5.57 \pm 0.61\end{array}$ & $\begin{array}{l}0.03 \pm 0.31(15) \\
0.03 \pm 0.32 \\
0.04 \pm 0.40\end{array}$ \\
\hline
\end{tabular}

The concentration of urea (tubule P27) and thiourea (tubule P28) in the perfusing solutions were, respectively, 5.5 and 7.2. $\mathrm{mM}_{\text {. }}$.The_values of $P_{D_{i}}$ are expressed as the mean ${ }^{-} \pm \mathrm{SD}$ for the numbers of flux periods shown in parentheses. 
drostatic pressure required to produce zero volume flow across the membrane. Since the osmotic pressure is an equilibrium potential $(15,16), \sigma_{1}$ is determined, in principle, at zero volume flow or during initial rates of volume flow (15). Because of technical limitations, it was not possible to make such measurements in the present experiments. Rather, two alternative approaches were used to estimate $\sigma_{t}$ for different solutes in these tubules.

In the first group of experiments, the osmotic "effectiveness" of different solutes, with respect to $\mathrm{NaCl}$, was evaluated by replacing, at constant osmolality, some of the $\mathrm{NaCl}$ in the bathing solutions with these solutes. The results (Tables I and II) indicate clearly that the observed water flows and values of $P_{\ell}$, in a given tubule, were not significantly altered when either sucrose or urea was used to replace, in part, the $\mathrm{NaCl}$ in the bathing solutions. However, when $n$-butanol was the test solute, the observed water flows could be rationalized in terms of the differences between the $\mathrm{NaCl}$ concentrations in perfusing and bathing solutions, and the control $P_{f}$ value for the particular tubule. In the second group of experiments, we evaluated the conditions for zero volume flow when test solutes were used to replace, in part, the $\mathrm{NaCl}$ in the perfusing and/or bathing solutions. The results indicate that, both in cortical (Table III) and outer medullary (Table IV) collecting tubules, there was zero net volume flow, within experimental error, when the perfusing and/or bathing solutions contained either urea and sucrose, so long as both solutions were isosmolal. Under these conditions, the rate-limiting site for the penetration of urea, and, by inference, sucrose and $\mathrm{NaCl}$, was the luminal interfaces (Fig. 1). Taken together, these experiments suggest that the $\mathrm{ADH}$-dependent reflection coefficients of $\mathrm{NaCl}$, sucrose and urea were identical, while that of butanol was near zero.

In this connection, the effective hydrodynamic radii of urea and sucrose are, respectively 1.8 and $5.2 \mathrm{~A}$ (17). Accordingly, it is likely that the ADH-dependent value of $\sigma_{1}$ for $\mathrm{NaCl}$, urea, and sucrose was unity at the luminal interfaces. In support of this view, $P_{D_{i}}$ for urea and thiourea in these tubules was indistinguishable from zero and unaffected by $\mathrm{ADH}$ (Table V), while the $\mathrm{ADH}$-dependent value of $\mathrm{P}_{\mathrm{D}_{\mathrm{w}}}$ is $14.3 \times 10^{-4} \mathrm{~cm}$ $\sec ^{-1}$. Thus, in agreement with previous observations on anuran epithelia $(18,19)$ and collecting tubules (13), we find no evidence for molecular seiving (5-8) of either urea or sucrose at the luminal interfaces of these tubules.

In previous studies, Morgan, Sakai, and Berliner (20) observed that, in the isolated rat papilla-collecting duct, the $P_{D_{i}}$ values for urea were $2 \times 10^{-4} \mathrm{~cm} \mathrm{sec}$ (without $\mathrm{ADH}$ ) and $3 \times 10^{-4} \mathrm{~cm} \mathrm{sec}^{-1}$ (with $\mathrm{ADH}$ ). It is likely that the lower urea permeability coefficients observed in the present experiments (Table V) relate to the fact that we used outer medullary collecting tubules. In contrast, the experiments of Morgan, Sakai, and Berliner (20) were carried out on collecting ducts from deeper, papillary collecting ducts.

Lastly, Hays, Franki, and Soberman have suggested that the effects of $\mathrm{ADH}$ on the water and urea permeability of the toad urinary bladder are referable solely to an increase in the rate of water diffusion across the luminal membranes of that tissue (21). In the preceding paper (1), a similar possibility was suggested for the luminal interfaces of these collecting tubules. Hays et al. have proposed that $\mathrm{ADH}$ increases the number of small aqueous channels in the luminal membranes of toad urinary bladder (21). These workers suggest that such channels are sufficiently small that they permit only diffusional water flow and effectively exclude small solutes (21). This hypothesis could account entirely for the effects of $\mathrm{ADH}$ on water and urea permeability in these tubules, if it is assumed that the $A D H-d e p e n d e n t ~ P_{r} / P_{D_{w}}$ ratio is referable to cellular constraints to diffusion (1). Alternatively, it should be recognized that $\mathrm{P}_{\mathrm{f}}$ in unmodified lipid bilayer membranes may range from $9.8 \times 10^{-4} \mathrm{~cm} \mathrm{sec}$ (22) to $104 \times 10^{-4} \mathrm{~cm} \mathrm{sec}^{-1}$ (23), depending on the composition of the lipid solutions used to form membranes. These values are within the range of the ADHdependent $P_{t}$ values for collecting tubules $(1,2)$. There is reasonable experimental evidence which indicates that the mode of water transport across unmodified lipid bilayer membranes is by a diffusion process (24-27). In addition, $\sigma_{1}$ for urea, $\mathrm{NaCl}$, sucrose, and other small hydrophilic solutes in such membranes is unity (28). These observations suggest that it is possible to rationalize the water and urea permeability of the luminal membranes of collecting tubules, with and without $\mathrm{ADH}$, in terms of diffusion through hydrophobic regions of the membranes. Stated in another way, the possibility remains that the effects of $\mathrm{ADH}$ on the water and urea permeability of these tubules are referable to modifications, as yet undefined, in the conformation and/or composition of hydrophobic regions in the luminal membranes.

\section{ACKNOWLEDGMENTS}

We are grateful to our research assistants S. L. Troutman and M. L. Watkins for their able assistance in carrying out these experiments.

This work was supported by research grants from the National Institutes of Health (AM-14873), National Science Foundation (GB-8479), and American Heart Association $(70-1047)$. 


\section{REFERENCES}

1. Schafer, J. A., and T. E. Andreoli. 1972. Celhular constraints to diffusion. The effect of antidiuretic hormone on water flows in isolated mammalian collecting tubules. J. Clin. Invest. 51 : 1264.

2. Grantham, J. J., and M. B. Burg. 1966. Effect of vasopressin and cyclic AMP on permeability of isolated collecting tubules. Amer. J. Physiol. 211: 255.

3. Ganote, C. E., J. J. Grantham, H. L. Moses, M. B. Burg, and J. Orloff. 1968. Ultrastructural studies of vasopressin effect on isolated perfused renal collecting tubules of the rabbit. J. Cell Biol. 36: 355.

4. Grantham, J. J., C. E. Ganote, M. B. Burg, and J. Orloff. 1968. Paths of transtubular water flow in isolated renal collecting tubules. J. Cell Biol. 41: 562 .

5. Pappenheimer, J. R., E. M. Renkin, and L. M. Borrero. 1951. Filtration, diffusion and molecular sieving through peripheral capillary membranes. Amer. J. Physiol. 167 : 13.

6. Renkin, E. M. 1955. Filtration, diffusion and molecular sieving through porous cellulose membranes. J. Gen. Physiol. 38: 225.

7. Durbin, R. P., H. Frank, and A. K. Solomon. 1956. Water flow through frog gastric mucosa. J. Gen. Physiol. $39: 535$

8. Kedem, O., and A. Katchalsky. 1961. A physical interpretation of the phenomenological coefficients of membrane permeability. J. Gen. Physiol. 45: 143.

9. Schafer, J. A., and T. E. Andreoli. 1970. Vasopressindependent reflection coefficients in isolated collecting tubules. Physiologist. 13: 302.

10. Schafer, J. A., and T. E. Andreoli. 1970. The effect of vasopressin $(\mathrm{ADH})$ on solute reflection coefficients in isolated collecting tubules. The 4th Annual Meeting American Society of Nephrology. Washington, D. C. 69.

11. Burg, M., J. Grantham, M. Abramow, and J. Orloff. 1966. Preparation and study of fragments of single rabbit nephrons. Amer. J. Physiol. 210: 1293.

12. Robbins, E., and A. Mauro. 1960. Experimental study of the independence of diffusion and hydrodynamic permeability coefficients in collodion membranes. J. Gen. Physiol. 43: 523 .

13. Burg, M., S. Helman, J. Grantham, and J. Orloff. 1970. Effect of vasopressin on the permeability of isolated rabbit cortical collecting tubules to urea, acetamide, and thiourea. In Urea and the Kidney. Bodil
Schmidt-Nielsen, editor. Excerpta Medica Foundation, Amsterdam. 193.

14. Staverman, A. J. 1951. The theory of measurement of osmotic pressure. Rec. Trav. Chim. Pays-Bas. 70: 344.

15. Katchalsky, A., and P. F. Curran. 1965. Nonequilibrium thermodynamics in Biophysics. Harvard University Press, Cambridge, Mass. 56.

16. Dainty, J. 1965. Osmotic flow. Symp. Soc. Exp. Biol. $19: 75$.

17. Schultz, S. G., and A. K. Solomon. 1961. Determination of the effective hydrodynamic radii of small molecules by viscometry. J. Gen. Physiol. 44: 1189.

18. Andersen, B., and H. H. Ussing. 1953. The contributions of diffusion and flow to the passage of $\mathrm{D}_{2} \mathrm{O}$ through living membranes. Acta Physiol. Scand. 28: 60.

19. Leaf, A., and R. M. Hays. 1962. Permeability of the isolated toad bladder to solutes and its modification by vasopressin. J. Gen. Physiol. 45: 921.

20. Morgan, T., F. Sakai, and R. W. Berliner. 1968. In vitro permeability of medullary collecting ducts to water and urea. Amer. J. Physiol. 214: 574.

21. Hays, R. M., N. Franki, and R. Soberman. 1971. Activation energy for water diffusion across the toad bladder: evidence against the pore enlargement hypothesis. J. Clin. Invest. 50: 1016.

22. Dennis, V. W., N. W. Stead, and T. E. Andreoli. 1970. Molecular aspects of polyene- and sterol-dependent pore formation in thin lipid membranes. J. Gen. Physiol. $55: 375$.

23. Huang, C., and T. E. Thompson. 1966. Properties of lipid bilayer membranes separating two aqueous phases: water permeability. J. Mol. Biol. 15: 539.

24. Cass, A., and A. Finkelstein. 1967. Water permeability of thin lipid membranes. J. Gen. Physiol. 50: 1765.

25. Everitt, C. T., W. R. Redwood, and D. A. Haydon. 1969. The problem of boundary layers in the exchange diffusion of water across bimolecular lipid membranes. J. Theor. Biol. $22: 20$.

26. Holz, R., and A. Finkelstein. 1970. The water and nonelectrolyte permeability induced in thin lipid membranes by the polyene antibiotics nystatin and amphotericin B. J. Gen. Physiol. 56: 125.

27. Andreoli, T. E., and S. L. Troutman. 1971. An analysis of unstirred layers in series with "tight" and "porous" lipid bilayer membranes. J. Gen. Physiol. 57: 464.

28. Andreoli, T. E., V. W. Dennis, and A. M. Weigl. 1969. The effect of amphotericin B on the water and nonelectrolyte permeability of thin lipid membranes. $J$. Gen. Physiol. 53 : 133. 